\title{
As imagens gráficas e a redefinição do imaginário republicano brasileiro
}

The graphic images and the redefinition of Brazilian republican imaginary

\author{
GALLAO, Karl Georges; Doutor; UFRJ \\ karlmuhs@hotmail.com.br \\ CIPINIUK, Alberto; Pós-doutor; PUC-Rio \\ acipiniuk@gmail.com
}

\begin{abstract}
Resumo
O artigo vai tratar da forma como se operou a trasladação de sentido do universo católico brasileiro, examinando especialmente a maneira como as imagens serviram como instrumentos operatórios a serviço de correntes ideológicas na legitimação e consolidação do novo regime republicano brasileiro. Nossa intenção é apresentar uma breve abordagem histórica para que possamos analisar em que medida as correntes ideológicas daquele período, também foram responsáveis pela construção de boa parte do imaginário cultural e social brasileiro, incluindo aí as imagens, os símbolos e os mitos, que formam a base da nossa cultura visual. Nossos esforços para este artigo podem ser compreendidos como uma contribuição para o Campo do Design na medida em que propomos repensar a imagem em relação ao seu aspecto cognitivo. Portanto, analisaremos como a violência simbólica influenciou a batalha dos símbolos e das alegorias, no conflito político em torno da imagem, em uma época decisiva para a nossa história.
\end{abstract}

Palavras Chave: imagem; design gráfico; história.

\begin{abstract}
The article will deal with the way in which the translation of the meaning of the Brazilian Catholic universe has been carried out, examining in particular the way in which the images served as operational instruments in the service of ideological currents in the legitimation and consolidation of the new Brazilian republican regime. Our intention is to present a brief historical approach so that we can analyze to what extent the ideological currents of that period were also responsible for the construction of much of the Brazilian cultural and social imaginary, including the images, symbols and myths that form the basis of our visual culture. Our efforts in this article can be understood as a contribution to the Field of Design as we propose to rethink the image in relation to its cognitive aspect. Therefore, we will analyze how symbolic violence influenced the battle of symbols and allegories, in the political conflict around image, in a decisive time for our history.
\end{abstract}

Keywords: image; graphic design; history. 


\section{A simbologia francesa como modelo de inspiração na construção do imaginário republicano}

O instrumento clássico de legitimação de regimes políticos através dos tempos, é naturalmente, a ideologia, a justificativa racional da organização de poder. Embora fundamentalmente de natureza discursiva (o verbo), os mecanismos ideológicos fizeram uso de elementos capazes de ampliar o poder comunicacional para fora do domínio da palavra, e para isso as instâncias de poder precisaram contar com a instrumentalidade das imagens, que desde o início dos tempos povoaram o imaginário social cultural.

Nesse artigo trataremos da forma como se operou a trasladação de sentido do universo católico brasileiro, examinando especialmente a forma como as imagens serviram como instrumentos operatórios a serviço de correntes ideológicas na legitimação e consolidação do novo regime republicano brasileiro depois da separação entre a Igreja e o Estado. Nossa intenção é apresentar uma breve abordagem histórica baseada nos escritos de José Murilo de Carvalho (CARVALHO, 1990) para que possamos analisar em que medida as correntes ideológicas ${ }^{1}$ em vigor naquele período histórico, aquelas que estiveram envolvidas na passagem do período Imperial para a República, também foram responsáveis pela construção de boa parte do imaginário cultural e social brasileiro, incluindo aí as imagens, os símbolos e os mitos, que no nosso entender formam a base da nossa cultura visual. Para o novo regime era necessário haver uma noção ideológica que o legitimasse ou que o justificasse, e que fosse além da força operada pelo arranjo oligárquico: ou bem diante a totalidade da população, ou pelo menos diante dos setores politicamente mobilizados. De qualquer maneira, pensamos que a construção do imaginário social da República foi capaz de romper com o círculo restrito das elites e atingir a população de modo geral, apesar da submissão das antigas associações e instituições religiosas ao poder clerical da ortodoxia romana depois da Questão Religiosa. Entendemos que o poder de permanência do universo simbólico religioso ainda estaria fortemente atrelado as nossas raízes coloniais, e, os republicanos tirariam proveito sobre o uso desses códigos visuais para obterem a aceitação da população e enfim se consolidarem.

A manifestação das visões republicanas para fora do círculo das elites dominantes ou tradicionais, ou a tentativa de operar essa manifestação, não poderia ter se concretizado unicamente por intermédio do discurso verbal, que seria inacessível a um público com baixo nível de educação formal. Pensamos, portanto, que essa manifestação apenas poderia ter sido operada mediante a sinais mais universais, de "leitura" mais facilitada, daí porque as imagens poderiam e foram aproveitadas nesse sentido, ou seja, na linha corrente do seu uso voltado para a prática política e social.

De fato, um exame preliminar da ação dos jacobinos e positivistas no Brasil nos revelaria o emprego de instrumentos tais como a imagem e os símbolos, que foram, por sua vez, particularmente empregados sob a inspiração francesa da época. O laicismo Republicano se manteria na França desde a Revolução Francesa, e os republicanos brasileiros se voltariam abertamente para a França como modelo de inspiração durante a implantação da República. Em vista dessa aproximação, aproveitariam parte da vasta reprodução do universo simbólico que

\footnotetext{
${ }^{1}$ Nos referimos às três correntes de pensamento que combateram intensamente pela definição do modelo de República: o liberalismo, o jacobinismo e o positivismo.
} 
permeou a Revolução de 1789, uma vez que esses símbolos seriam implementados aqui. ${ }^{2}$

A exemplo da simbologia francesa, o barrete frígio $^{3}$, forte símbolo de inspiração libertária do regime republicano francês, seria absorvido como parte da história da nossa cultura visual, ainda que passasse despercebido aos olhos de muitos. Na heráldica brasileira o barrete aparece ainda hoje no centro do brasão da bandeira da cidade do Rio de Janeiro, ao fundo do escudo azul português. Da mesma forma como também está presente nos brasões dos estados do Acre, Amazonas, Bahia, Paraíba, Rio Grade do Sul e Santa Catarina como parte da iconografia nacional. Aliás, poucas pessoas notariam que o mesmo barrete ganharia notoriedade no folclore brasileiro como parte da indumentária do pequeno negrinho zombeteiro de uma perna, o Saci-Pererê (CÂMARA CASCUDO, 1999, p.794). Durante o Império Romano o barrete frígio, também conhecido como pileus romano era utilizado pelos antigos escravos que haviam conquistado sua

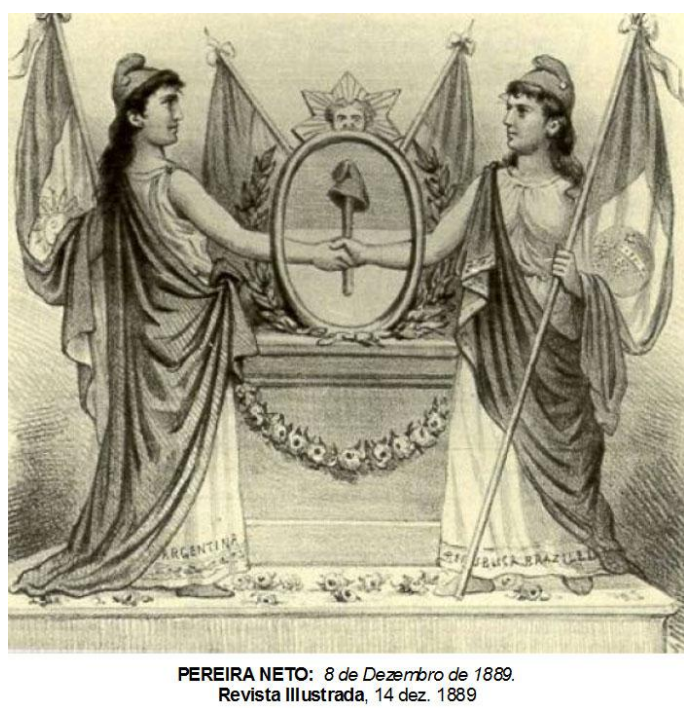

Figura 3 - Imagem "8 de dezembro" desenhada por Pereira Neto e publicada em 14 de dezembro de 1889 na Revista Illustrada. A República brasileira confraterniza com sua irmã argentina. As duas repúblicas são representadas por mulheres vestidas a romana, descalça ou sandálias, barrete frígio. FONTE: CARVALHO, José Murilo de. Os bestializados: $O$ Rio de Janeiro e a República que não foi. São Paulo: Companhia das Letras, 1987, p. 82. emancipação. Assim, embora a figura do Saci tenha surgido somente em meados do século XIX, pois até onde se sabe não foi mencionada pelos cronistas do Brasil colonial, acreditamos que talvez a razão da presença do seu capuz pudesse estar condicionada iconologicamente em vista da Abolição da Escravatura sancionada em 1888: um ano antes da Proclamação da República. Nesse caso, o barrete do Saci poderia nos indicar que a entidade viria a se tratar de um negro livre. E ainda, que a implantação da simbologia republicana surtiria alguns efeitos duradouros, mais quanto à imagem, do que propriamente seu significado.

Seria importante salientar que em escala menor do que no período da Revolução Francesa, com o início do período republicano que se sucede no Brasil, também seria travada uma batalha de símbolos e alegorias, ou guerra de imagens como Gruzinsky chamou (GRUZINSKI, 2006). Essa batalha seria na verdade uma continuação da colonização do imaginário, tal como a política religiosa de dominação do imaginário iniciada por Portugal ainda no Primeiro Reinado. E essa relação de dominação seria ainda

\footnotetext{
${ }^{2}$ Descrições de época trariam referências dos republicanos brasileiros de cantarem a Marselhesa, de representarem a República com o barrete frígio; informam também sobre a luta dos positivistas pela nova bandeira e sobre a disputa em torno da definição do panteão cívico do novo regime. A respeito do entusiasmo pela Revolução Francesa, um oficial da Marinha expressaria no jornal O PAIZ: "Todas as nossas aspirações, todas as preocupações dos republicanos da propaganda, eram de fato copiadas das tradições francesas. Falávamos na França bem-amada, na influência da cultura francesa, nas menores coisas das nossas lutas políticas relembrávamos a França. A Marselhesa era nosso hino de guerra, e sabíamos de cor os episódios da grande revolução. Ao nosso brado 'Viva a República!' seguia-se quase sempre o de 'Viva a França!'. [...] A França era nossa guiadora, dela falávamos sempre e sob qualquer pretexto". Depoimento feito a O PAIZ em 20/11/1912, passim.

${ }^{3} \mathrm{O}$ barrete frígio (pileus romano) poderia ser compreendido como uma espécie de touca ou capuz de cor vermelha adotado pelos republicanos franceses durante a revolução de 1789 como símbolo de liberdade.
} 
parte integrante de uma disputa ideológica e política. Uma disputa em torno da imagem do novo regime, cuja finalidade era atingir o imaginário popular para recriá-lo dentro dos valores republicanos. A elaboração do imaginário é uma parte integrante da legitimação de qualquer regime político. Por intermédio do imaginário que se pode atingir mais do que a cabeça ou a mente, mas o coração, isto é, as aspirações, os medos e as esperanças de um povo. É nele que as sociedades definem suas identidades e objetivos, modelam condutas sociais, definem seus inimigos, organizam seu passado, presente e futuro (BACKZO, 1984).
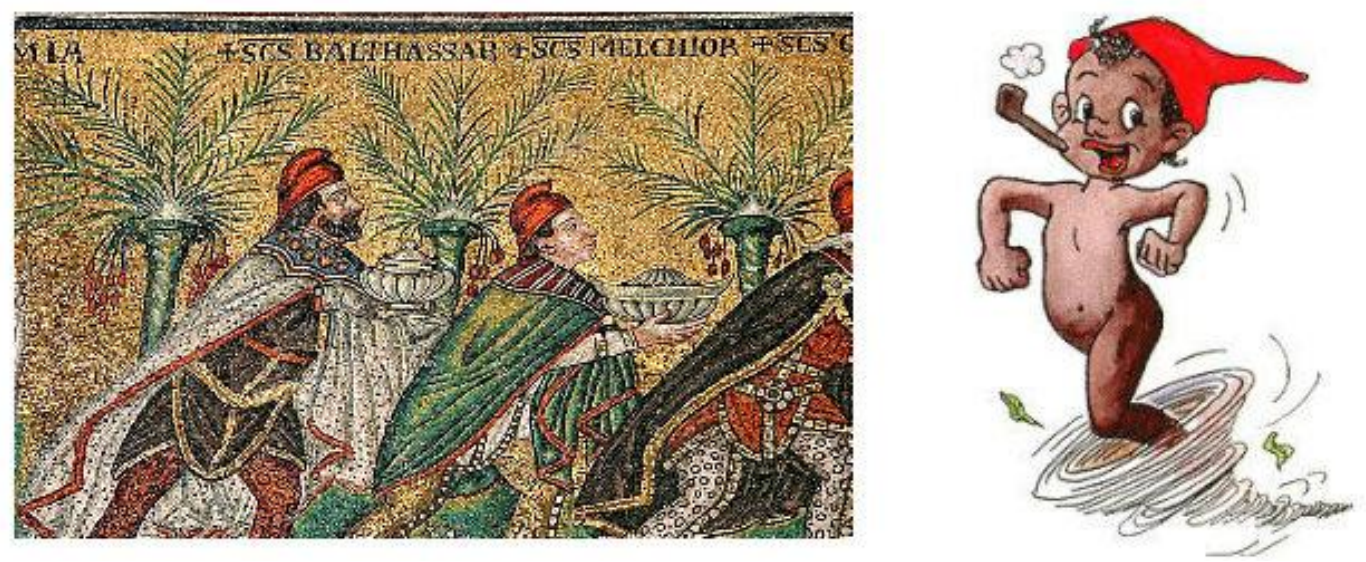

Figuras 1, 2- Mosaico do final do século VI representando os Três reis magos vestindo barretes frígios. FONTE: https://pt.wikipedia.org/wiki/Barrete_fr\%C3\%ADgio\#/media/File:Magi_(1).jpg / A direita, uma ilustração do personagem do folclore brasileiro, o Saci-Pererê, vestindo o barrete vermelho. FONTE: http://brasilescola.uol.com.br/folclore/saci-perere.htm

Tal como ocorreu no período colonial, a ocidentalização não poderia ser compreendida apenas pelos caminhos da cristianização e imposição do sistema colonial. Para que ocorresse um câmbio de tal magnitude, seria necessário também uma transformação de processos mais profundos e mais determinantes: a mutação da temporalidade e da crença, uma transformação dos códigos visuais, e a redefinição do imaginário e do real, enfim, de toda uma cultura tal como no caso dos índios americanos, quando foram obrigados a submeter-se e expressar-se (GRUZINSKI, 2006, p.410). Defendemos que de forma ainda mais autoritária e brutal do que a dominação colonial, a dominação do imaginário pela cultura religiosa Ibérica, inferiu não apenas na lógica racional da mente humana, mas nos sentimentos mais profundos de uma sociedade. Logo, a manipulação do imaginário social carregaria uma distinta importância na redefinição das identidades coletivas e sociais em momentos de transformações políticas. Ao mesmo tempo, diríamos que apesar do imaginário social ser constituído e expressado pelo pensamento ideológico, ele apenas tomaria forma concreta e se materializaria por meio das imagens, que, por sua vez, garantiriam o seu poder de permanência ancorando-se na cultura visual da sociedade. Embora a separação entre a Igreja e o Estado fosse uma demanda atraente para os positivistas da república, o imaginário social constituído pelo cristianismo estaria fortemente consolidado pela Monarquia. Caberia aos republicanos saber como utilizar seus códigos religiosos em favor dos seus interesses políticos e ideológicos. 
É preciso dizer que a República brasileira, diferente do modelo francês, ou do americano, não possuía suficiente densidade popular para refazer o imaginário nacional. Suas raízes populares eram escassas, alcançando apenas os setores minoritários da população, ou seja, camadas sociais de estratificação mais elevada. Apenas quando se voltou para as tradições culturais mais profundas, por vezes alheias à sua imagem, tal como a religiosidade cristã, foi que pode alcançar algum êxito em se popularizar. Esse momento aconteceu quando apelaram para a religião - como no caso de Tiradentes e de Nossa Senhora da Aparecida. As queixas dos republicanos em relação a falta de capacidade do novo regime de gerar entusiasmos costumavam ser frequentes, e apelavam ao governo para que se esforçasse mais por despertar o entusiasmo nas pessoas por meio desses poderosos instrumentos de propaganda (JÚNIOR, 1980, p. 2-3). Apesar de possuírem suas razões para povoar o imaginário social, perguntamo-nos em que medida a simbologia da cultura visual religiosa cristã consagraria a imagem do herói da Inconfidência ou ofuscaria a alegoria republicana pela invocação de uma santa negra? Seriam as imagens que conhecemos hoje sobre nossa própria história parte de uma política de dominação?

Nesse caso, não se trata de modo nenhum de uma característica inata das imagens como "coisas em si", possuindo uma condição objetiva que Ihes garantiria uma essência ou natureza singular, mas a comprovação de que a verdade das imagens está nos olhos de quem as vê, sendo que não se trata de defender a dimensão subjetiva que Kant mencionava, mas a presença de uma cultura visual que é inculcada de modo intencional ou político, tornando-se aparentemente natural para as pessoas que as observam naquele período histórico. $O$ fato é que o imaginário social popular que se apresenta nas representações gráficas das imagens religiosas, invariavelmente precede a formulação conceitual, escapando à sua rigidez e aos seus constrangimentos. Exibiria potencialidades que, na origem, o discurso ortodoxo não conseguiria conceber, ou melhor, as imagens, dependendo da intenção de seus produtores, desencadeariam efeitos que escapariam constantemente àqueles que a empregavam para outros fins no princípio. A imagem nunca circulou de forma neutra, sem um propósito antes pensado, como se pudesse supor o real em si mesmo como uma verdade. Não teríamos clareza consciente, na maioria das vezes, de intuir suas motivações ideológicas. Isto porque nos faltam as distinções sobre o que é isso que é uma imagem e sobre aquilo que parece ser uma imagem.

\section{A construção da imagem sobre o mito do herói Tiradentes}

Para se pensar uma imagem no seu melhor sentido de potência simbólica, os heróis costumam ser compreendidos como símbolos cívicos, encarnações de ideias e fulcros de identidade coletiva. Carregam características que os tornariam instrumentos eficazes para atingir a cabeça e o coração dos cidadãos a serviço da legitimação de regimes políticos. No Brasil, a luta em torno do mito de origem da República apresentaria uma certa dificuldade na construção de um herói que viesse a representar o novo regime, pois era necessário produzir e exaltar um envolvimento real dessa figura mítica com o as camadas sociais menos favorecidas, o povo. A personagem teria de evocar algum tipo de personalidade ou comportamento que correspondesse a um modelo coletivamente valorizado. Em outras palavras, esse herói deveria possuir a cara do seu povo. Na falta dessa proximidade, o esforço de mitificação de figuras políticas, candidatos a heróis e não menos importantes para a nossa história - como Deodoro da Fonseca, Benjamin Constant e Floriano Peixoto -, resultaria em vão, ou melhor, acabariam ignorados pela maioria da população. Desse 
modo, quem aos poucos se revelaria capaz de atender as exigências da mitificação foi um dos líderes da Conjuração Mineira, José Joaquim da Silva Xavier, o Tiradentes. Seria importante ressaltar que em torno dessa figura emblemática aconteceram muitas discussões historiográficas, principalmente entre os adeptos da República e os adeptos da Monarquia. No entanto, a disputa sobre seu verdadeiro papel na Inconfidência, sobre a sua personalidade, sobre as suas conviç̧ões, sobre a sua aparência física, poderia nos trazer importantes elementos para a construção do mito e da concretização de uma imagem que iria prevalecer através dos tempos. O domínio e a construção do mito se refletiria no imaginário social, que, por sua vez, viria a se manifestar na tradição escrita e oral. A formação do mito poderia então se manifestar contra a evidência documental inclusive, pois o imaginário seria capaz de interpretar evidências segundo os mecanismos simbólicos religiosos, nesse caso, que the são próprios e que não se enquadrariam necessariamente na narrativa histórica. A partir dos mecanismos simbólicos seria possível estabelecer uma historiografia no sentido de enaltecer a figura de Tiradentes, relacionando diretamente sua história e imagem à figura histórica de Cristo.

As revelações do historiador Joaquim Norberto de Souza Silva ${ }^{4}$ - embora mais "verdadeiras" do ponto de vista histórico, mas em discordância a versão patriótica narrada sobre a vida do mártir -, despertaram enorme irritação por parte dos republicanos por relatar um Tiradentes católico e piedoso. Nela Norberto relata que o inconfidente foi sido transformado em um místico por conta da experiência traumática que sofrera enquanto esteve preso, e principalmente por conta de uma
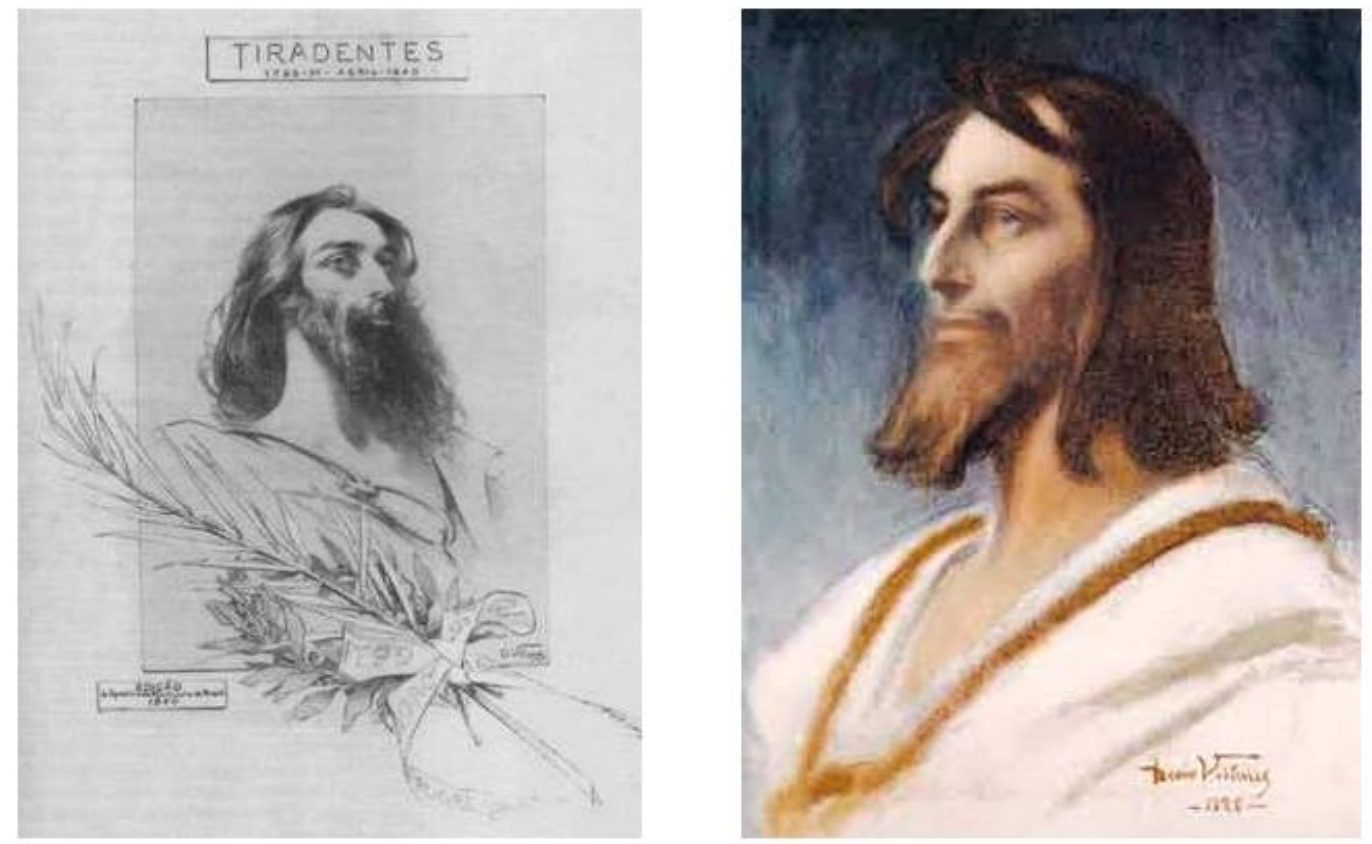

Figuras 12, 13 - Tiradentes, litografia, Décio Villares, Igreja Positivista do Brasil. / Tiradentes, óleo, Décio Villares, Museu Mariano Procópio. Em ambas as obras é possível notar a estilização de Tiradentes para aproximá-lo a figura de Cristo. FONTE: CARVALHO, José Murilo de. Os bestializados: O Rio de Janeiro e a República que não foi. São Paulo: Companhia das Letras, 1987, p. 98.

\footnotetext{
${ }^{4}$ Joaquim Norberto de Souza Silva, chefe de seção da Secretaria do Estado do Império e vice-presidente do Instituto Histórico, revelou importantes documentos - os Autos da Devassa, até então desconhecidos, em sua obra História da Conjuração Mineira de 1873 -, tomando parte nas discussões em torno do mito de Tiradentes.
} 
verdadeira lavagem cerebral que os frades franciscanos Ihe aplicaram (SILVA, 1948). O prolongado período de reclusão, os repetidos interrogatórios e a ação dos franciscanos, poderiam de fato ter comprometido o comportamento e a personalidade de Tiradentes. Por esse motivo, seria possível admitir que o próprio Tiradentes tivesse feito menção à morte de Cristo dizendo que Nosso Senhor também morrera nu por seus pecados, quando recusou-se a vestir a roupa por baixo da alva (CARVALHO, 1990, p. 63). O beijo nos pés do carrasco, outra referência clara ao perdão de Cristo aos seus algozes, e a marcha para fora em solilóquios com o crucifixo que os frades lhe tinham colocado entre as mãos atadas, também seriam vistos como parte do universo simbólico do catolicismo, qual Tiradentes teria tomado para si (CARVALHO, 1990, p. 64).

Outra evidência dessa aproximação aos códigos do cristianismo seria o pintor positivista Décio Villares, que durante o desfile que passou a fazer parte das comemorações do 21 de abril, dia declarado como feriado nacional em 1890, teria distribuído uma litogravura onde representava o busto de Tiradentes com a corda no pescoço, ornado com a palma do martírio e os louros da vitória. A imagem idealizada de Tiradentes fora representada com barba e cabelos longos, ar sereno e olhar no infinito. Ora, não existia nenhum retrato de Tiradentes elaborado por alguém

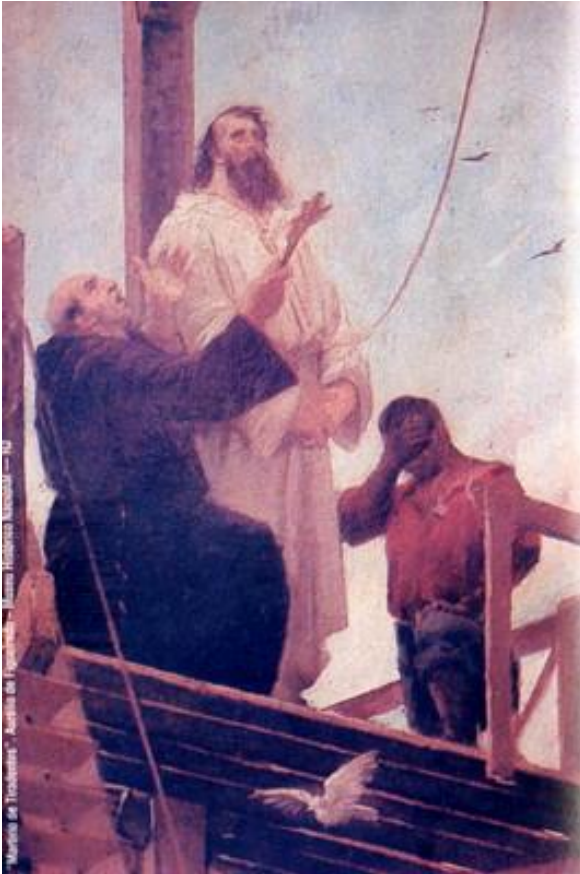

Figura 14 - Obra O Martírio de Tiradentes, de Aurélio de Figueiredo, também estabelece uma relação de proximidade entre a figura de Tiradentes e Cristo. Museu Histórico Nacional. FONTE: CARVALHO, José Murilo de. Os bestializados: $O$ Rio de Janeiro e a República que não foi. São Paulo: Companhia das Letras, 1987, p. 98. que o tivesse conhecido pessoalmente. Destarte, o que predominaria quando Décio Villares produziu sua versão na obra seria sua contestação a descrição retirada do livro de Joaquim Norberto, quando baseando-se na declaração de Alvarenga Peixoto, descrevera Tiradentes como "feio e espantado". Mais tarde, em 1928, Villares voltaria a retratar o inconfidente numa nova representação que seria o desenvolvimento da primeira, ou melhor, uma maior estilização da figura com cabelos e barba menos revoltos. A partir das revelações de Norberto e, talvez, da própria tradição oral, as representações plásticas e literárias de Tiradentes, e mesmo as exaltações políticas, passariam a utilizar cada vez mais a simbologia religiosa e a aproximá-lo da figura de Cristo. ${ }^{5}$

Além do óbvio apelo à tradição cristã do povo, que facilitaria a transmissão da imagem de um Cristo cívico, o cerimonial do enforcamento, o cadafalso, a forca erguida a altura incomum, os soldados ao redor, a multidão de expectadores - todos esses elementos contribuiriam para aproximar os dois eventos e as duas figuras, a crucificação e o enforcamento, Cristo e Tiradentes. 0 esquartejamento posterior, o sangue derramado, a distribuição das partes pelos caminhos que antes percorrera também serviria ao simbolismo da semeadura do sangue do mártir. O patriota viria enfim a se tornar

\footnotetext{
${ }^{5}$ A simbologia cristã também ressurge em várias outras obras de arte da época como no quadro Martírio de Tiradentes, de Aurélio de Figueiredo; e em Tiradentes Esquartejado de Pedro Américo que se encontra do Museu Mariano Procópio na cidade de Juiz de Fora, Minas Gerais.
} 
místico, isto é, assumindo explicitamente sua postura como mártir e identificando-se abertamente a imagem de Cristo. Tiradentes teria se transformado enfim no herói republicano.

\section{A força identitária popular de Nossa Senhora da Aparecida}

A substituição do cívico pelo âmbito do religioso terminou por prevalecer também quanto a imagem alegórica da República. Com a queda do Império, a apropriação da imagem feminina, da simbologia cívica francesa, deveria fazer frente ao Antigo Regime de modo a enaltecer não apenas os ideais libertários e patrióticos da Revolução, mas ainda os valores positivistas. Para eles a mulher era o símbolo ideal de organização da pátria, ou seja, quem melhor representaria a base para a convivência social em uma sociedade sem a figura de Deus. O repúdio ao patriarcalismo do Imperador Dom Pedro II, que teria apontado uma dificuldade em aceitar uma sucessora feminina no trono, também seria um fator que contribuiria para a representação da República como mulher. Todavia, haveria um sentimento muito mais profundo de associação identitária com a simbologia feminina, incorporado a sociedade brasileira muito antes, desde a chegada das primeiras expedições vindas de Portugal. Seria a figura da Virgem-Mãe, poderosa e intercessora infalível, Maria, a compadecida. No final do século XVIII a mariolatria católica ainda era um impedimento real aos republicanos, que embora apoiassem o uso da representação feminina para a humanidade, se esforçariam em substituir a imagem da Virgem Maria pela imagem de Clotilde de Vaux - famosa musa inspiradora de Auguste Comte e uma das representações figurativas da alegoria homologamente ao modelo clássico de Palas Atena (CARVALHO, 1990, p. 93). A separação da Igreja e Estado efetivada pela república geraria forte revolta entre a população, como ocorreu no caso do confronto da Guerra de Canudos. Portanto, o uso de um símbolo católico pela República poderia fazer parecer profanação.

Em todo caso, ainda que evitassem acirrar os ânimos com o povo, os republicanos não seriam capazes de conter a vontade da população sobre a figura feminina símbolo da pátria. Tanto na França do Segundo Império quanto no Brasil da Primeira República a figura de Maria teria sido empregada como arma antirrepublicana. Deliberadamente os bispos se esforçaram para incentivar o culto mariano, sobretudo por meio de Nossa Senhora da Aparecida. No início do século XX começaram as romarias oficiais, e em 8 de setembro de 1904, Nossa Senhora da Aparecida foi coroada rainha do Brasil: dia seguinte a comemoração da independência uma designação monárquica. Sem conseguir mais conter o acirramento entre a Igreja e o Novo Regime pela representação da nação, em 1930, o papa Pio IX declararia Nossa Senhora Aparecida padroeira do Brasil. No ano seguinte, D. Sebastião Leme, perante uma multidão congregada no Rio de Janeiro, a consagraria rainha e padroeira do país. Ainda que a representação de N. S. Aparecida fosse problemática, ela sem dúvida superaria qualquer outra figura feminina, ou mesmo todos os símbolos cívicos. Pois além de possuir raízes na profunda tradição católica e mariana, apresentaria a vantagem adicional de ser brasileira e negra, o que viria impor uma distância significativa à representação francesa e branca de Clotilde de Vaux. Enfim, a batalha pela alegoria feminina terminaria na derrota republicana perante a política de dominação católica. O programa de infestação de impressos gráficos religiosos implementado pelas missões dos jesuítas nas Américas durante o período da Contrarreforma teria, em outras palavras, se comprovado mais eficaz no sentido de povoar o imaginário de uma sociedade. Tal como foi o caso da Virgem do Guadalupe no México, Nossa Senhora Aparecida se tornaria parte da matriz cultural tradicional do catolicismo brasileiro, atestando seus milagres e trazendo conforto para a vida de milhões. 
Para os positivistas republicanos o Brasil era um território aberto a grandes transformações. Consideravam-se em posição privilegiada para apressar a marcha da história, daí porque se lançariam a doutrinação política com demasiada convicção. Assim, enquanto esta ação viesse a se basear no âmbito do convencimento ideológico, empregariam o uso dos símbolos e das imagens. Em primeira instância, a palavra escrita e falada - qual fariam uso abundante em livros, jornais, publicações da Igreja, conferências públicas -, seria a arma principal de convencimento dos setores sociais médios. Em paralelo empregariam também as imagens impressas com suas simbologias culturais, tendo em vista dois públicos estratégicos: as mulheres e os proletários, que por conta da baixa escolaridade seriam menos afetos à palavra escrita (CARVALHO, 1990, p. 140). Caso a propaganda não fosse capaz de convencê-los da verdade de sua doutrina, todo esforço dos positivistas na proclamação da República cairia no vazio. Daí porque se envolveriam com afinco na batalha pelos corações e mentes dos cidadãos por meio dos símbolos e das imagens: na luta pelos monumentos, pelo mito de Tiradentes e pela figura feminina. Sobre suas conviç̧ões, os republicanos acreditariam que o papel de protagonista político caberia às classes educadas, daí porque fariam com que sua influência maior fosse exercida sobre as elites. Nos casos em que sua ação política iria de encontro as tradições populares, seu único mérito seria o de ter contribuído de maneira substantiva para a construção do pouco que subsistiu do imaginário republicano até hoje.

Que por mais não fosse, tirando uma ou outra imagem isolada, como no caso do próprio personagem do Saci, as correntes republicanas não foram capazes de concretizar a reprodução de um imaginário popular republicano tão significativo quanto a ideologia religiosa do catolicismo. Nos aspectos em que foram bem sucedidos, na maior parte de vezes, o motivo seria em razão dos

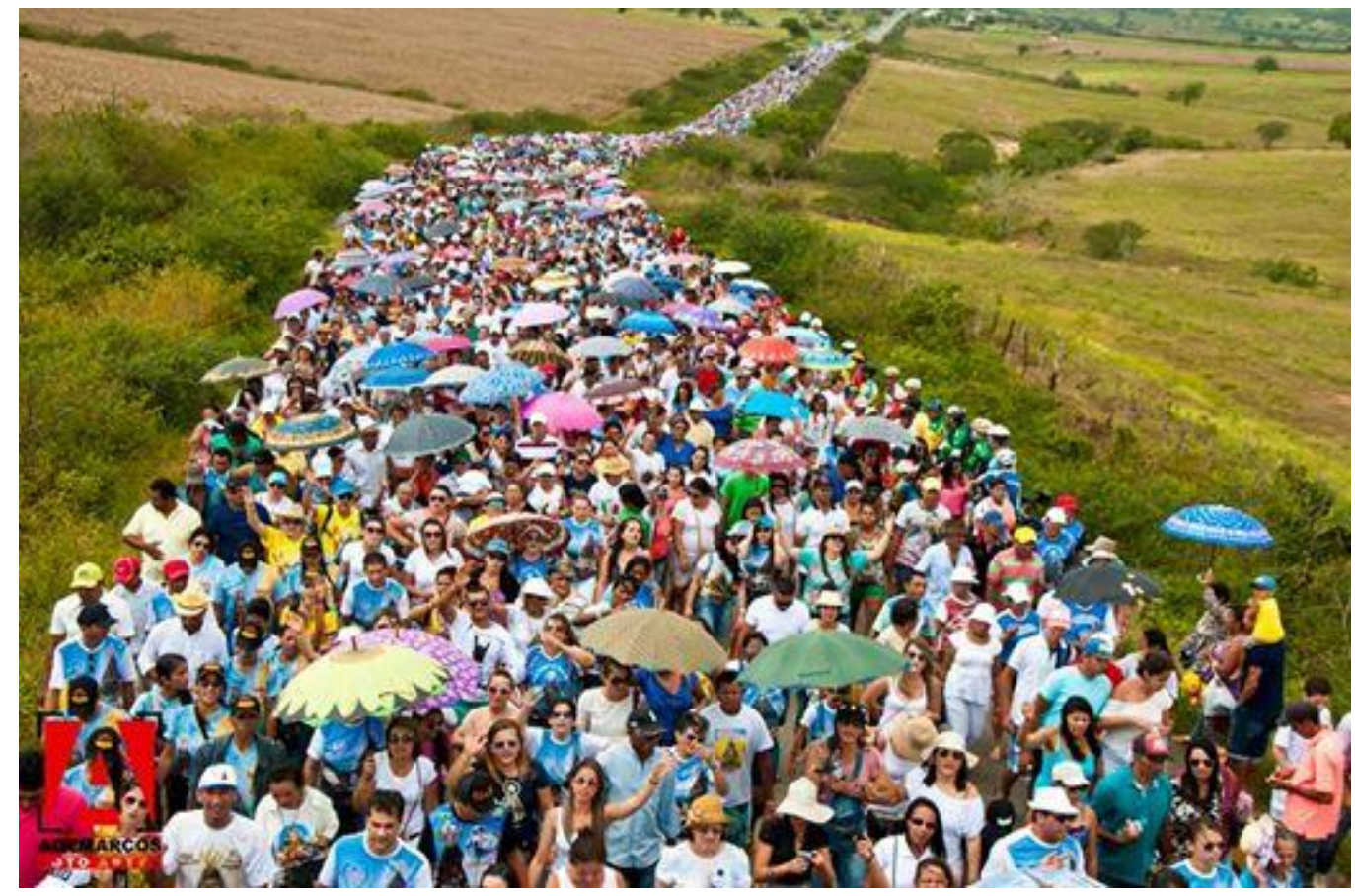

Figura 15 - Milhares de devotos para a festa e romaria em homenagem à Padroeira do Brasil e do município de Sergipe, Nossa Senhora da Aparecida: cerca de cem mil fiéis peregrinam pela rota do sertão. FONTE: http://www.missaoaparecida.com/2015/10/romaria-de-nossa-senhoraaparecida-se.html 
compromissos com a tradição imperial ou com os valores religiosos do catolicismo. O esforço despendido não teria sido suficiente para romper com a barreira criada pela ausência de envolvimento popular na implantação do novo regime. Boa parte da simbologia republicana seria esquecida, como aconteceria particularmente com a alegoria feminina, por falta de participação na vivência coletiva, e principalmente, por falta de uma política de propaganda superior a anterior. Desse modo, a falta de imagens para a materialização de uma identidade republicana e a persistente emergência de ideais conflitantes corroborariam para compreender o êxito da figura do herói personificado em Tiradentes. Com barba ou sem barba, o que importaria seria a disputa pela sua imagem. Junto a sua figura, apesar dos desafios que surgiriam com as novas correntes religiosas, talvez fosse ainda a imagem da N. S. Aparecida a que melhor conseguiria oferecer um sentido de comunhão nacional as grandes massas da sociedade. Um sentido que na ausência de um civismo republicano, apenas poderia existir fora do domínio da política republicana.

\section{Da crítica à respeito da construção do mito sobre a imagem na história}

Portanto, se considerássemos a visão como produto de um processo de acúmulo de experiência e aculturação, incluindo aí a experiência de fazer imagens, então o que estaríamos relacionando com a representação pictórica não seria um tipo de realidade neutra, mas um mundo prefixado em um sistema de representações visuais, que por sua vez, corresponderia a uma ou mais ideologias em específico. As representações e as condutas - sejam elas religiosas ou meramente políticas - que invocam uma mensagem original única e permanente, devem sua difusão no espaço social ao fato de que recebem significações e funções radicalmente distintas por parte dos diferentes grupos. Em cada formação social e em cada época, toda a visão de mundo e todas as formas de representação visual material, dependem das condições sociais características dos diferentes grupos, na medida em que devem adaptar-se a estas condições - e às condições anteriores - para dar conta de sua produção. Ressaltamos que esse artigo argumenta em defesa de um relativismo mais rigoroso, que vai considerar o conhecimento como um produto social, uma questão de diálogo disso que os acadêmicos de hoje chamam de diferentes linguagens e nós preferimos denominar de interesses ideológicos, que promoveriam a imagem como modo de representação que, por sua vez, reafirmaria essas mesmas noções.

Da crítica à respeito da construção do mito sobre a imagem na história, compreendemos que ela tendeu a negar sua origem real e sua natureza de objeto fabricado para se afirmar como um artefato quase consubstancial a seu protótipo sagrado. Longe de uma neutralidade, é preciso afirmar a noção de que as imagens exercem um controle social sofisticado e, a partir de seu uso, em razão de uma política voltada para um posicionamento ideológico específico da cultura dominante de uma determinada época. Desse sofisticado controle ou censura sobre a configuração que determinam os códigos visuais que serão transmitidos, afirmamos que existem instâncias de legitimação política poderosas, voltadas para o mercado da circulação dos bens simbólicos e que em diferentes épocas estiveram em relação direta ao sistema social, orientado pelo modo de produção vigente. Assim, desde a queda da aristocracia, e da consolidação da democracia representativa e do Estado de direito no século XIX, a transformação das relações capitalistas sobre os modos de produção permitiu que o controle da dominação simbólica estivesse atrelado à censura econômica, na medida em que as instâncias de dominação precisaram da hegemonia econômica para se perpetuar. 
Ao estabelecer uma associação dessa relação entre economia e política com o nosso tempo, sugerimos um viés que se localiza fora da vertente da filosofia tradicional do Campo Científico do Design, onde os processos cognitivos ou comunicacionais da imagem seriam explicados de outra maneira, como que em razão de propriedades sensoriais ou psicológicas individuais. ${ }^{6}$ Nossos esforços para este trabalho são, em parte, uma estratégia de desmascarar aquilo que muitos dos pares do Campo do Design ocultam ou ignoram. Nossa função é desvelar esses mecanismos ocultos dentro dos processos políticos e históricos. Identificar onde se desenvolveram, e ao fazêlo, poder contribuir para tornar conhecida suas formas de controle que se exerce pelas imagens nas relações sociais e, em particular, nas relações de comunicação visual cumprida pelas instâncias de dominação, como no caso dos veículos de comunicação no nosso tempo. Estudando as ações do passado e dos dias de hoje, verificamos que os efeitos compreendidos pelos processos históricos da cultura visual apenas no âmbito da antropologia cristã do Ocidente, confirma-se a sua força de pregnância ainda no tempo presente. Destarte, os veículos comunicacionais que servem de suporte para as imagens, continuaram, em seus novos formatos tecnológicos, a exercer seu poder de monopólio sobre a formação dos corações e mentes.

\section{Referencias}

BACZKO, Bronislaw. Les imagineires sociaux. Mémoires et espoirs collectifs. Paris: Payot, 1984.

CÂMARA CASCUDO, Luís da. Dicionário do Folclore Brasileiro. Rio de Janeiro: Ediouro, 10a ed., 1999.

CARVALHO, José Murilo de. A Formação das Almas: 0 imaginário da República no Brasil. São Paulo: Companhia das Letras, 1990.

das Letras, 1987.

Os bestializados: O Rio de Janeiro e a República que não foi. São Paulo: Companhia

GRUZINSKI, Serge. A guerra das imagens: de Cristóvão Colombo à Blade Runner (1492-2019). São. Paulo: Companhia das Letras, 2006.

JÚNIOR, Thomé. "Já é tempo!", Revista Illustrada, №. 590 (maio, 1980).

LEITE, Ricardo de Souza. Ver é compreender: design como ferramenta estratégica de negócio. Rio de Janeiro: Editora Senac, 2003.

SILVA, Joaquim Norberto de Souza. História da Conjuração Mineira. Rio de Janeiro: Imprensa Nacional, 1948.

\footnotetext{
6 "É no primeiro contato que se baseia grande parte de nosso julgamento de valor. O contato inicia-se, geralmente por meio de uma confrontação com a imagem, quando a solução visual traduz a mensagem a ser identificada e compreendida. A forma precede o conteúdo. Mesmo quando os dois ocorrem aparentemente ao mesmo tempo, a mensagem visual antecede a experimentação." (LEITE, 2003).
} 